\title{
Geriatric dentistry teaching and the curricular guidelines in dental schools in South American countries
}

María del Rosario Ruiz Núñez' Jussara Gue Martini ${ }^{2}$ Mônica Joesting Siedler ${ }^{3}$ Ana Lúcia Schaefer Ferreira de Mello?

Abstract

Objective: to analyze the teaching of geriatric dentistry from the perspective of the National Curricular Guidelines (NCG) for undergraduate courses in dentistry in South American countries. Method: an exploratory and descriptive study with a qualitative approach was carried out, covering the dental schools of public universities in five South American countries which included a geriatric dentistry module in their curriculums. Twenty intentionally selected participants were included. Semi-structured open interviews were recorded using digital media and the content was analyzed using the Thematic Analysis technique with Atlas-Ti® software, based on the current NCG in each country. Results: the NCG evaluated in the five countries were similar in terms of the norms that guide the education of the dental surgeon. Three categories of analysis were identified: professional profile, skill development and the geriatric dentistry teaching-learning process for the undergraduate student. Conclusions: dentistry teaching has sought to connect with the NCG. However, the simple insertion of a geriatric dentistry module in the curriculum is not sufficient to promote a teaching-learning process that allows the student to develop skills to provide better care for the elderly.

\footnotetext{
Universidade Federal de Santa Catarina, Departamento de Odontologia, Programa de Pós-graduação em Odontologia. Florianópolis, Santa Catarina, Brasil.

2 Universidade Federal de Santa Catarina, Departamento de enfermagem, Programa de Pós-graduação em Enfermagem. Florianópolis, Santa Catarina, Brasil.

3 Universidade Federal de Santa Catarina, Núcleo de Estudos da Terceira Idade. Florianópolis, Santa Catarina, Brasil.
}

Keywords: Geriatric Dentistry. Teaching. Curriculum. Aging. Elderly. 


\section{INTRODUCTION}

In recent decades there has been an accelerated increase in the length of human life in developing countries. In South American nations such as Brazil, Peru, Colombia, Chile and Argentina elderly persons represent an expressive proportion of the population ${ }^{1-5}$. According to projections by government bodies, the elderly represent approximately $15 \%$ of the total population in Chile and Argentina. In Brazil, this age group constitutes $12.5 \%$ of the total population, while in Colombia and Peru the percentages of elderly persons reach $11.9 \%$ and $10.2 \%$, respectively ${ }^{1-5}$.

Physical and social alterations that can compromise the health status of individuals occur throughout the aging process and are therefore considered a challenge to be tackled by society ${ }^{6}$. With the increase in the global elderly population, dentistry also faces different challenges. One is the professional training of those who will be responsible for the care of the elderly population. It is important that there is contact with geriatric and gerontology knowledge throughout the training and education process, as well as the development of appropriate teaching practices, including those relating to oral health?

Geriatric dentistry has been established in the curricula of undergraduate dentistry courses since the 1980s. In Brazil and other countries of South America, the subject is a recent addition to undergraduate studies. The general purpose of this is to enable students to meet the oral health needs of the elderly in a responsible and suitable manner ${ }^{8}$. In other words, it is not only about knowledge of the oral cavity of the elderly, but about integrated human recognition from a physical, emotional, intellectual and social point of view, as this age group is made up of people with highly heterogeneous characteristics? The content of geriatric dentistry aims to allow students to develop the skills necessary to effectively manage this population group and to enable them to provide more humanized and quality care ${ }^{10}$.

The training of the future dental surgeon occurs within different contexts, with the purpose of training professionals who are prepared to care for the wellbeing of the population. From this perspective, the National Curricular Guidelines (NCG) in dentistry courses were created by the need to make changes to the curriculum and for the professionalization of teaching work. NCG define how future dental surgeons should be trained in terms of principles, fundamentals, conditions and procedures. This professional training should allow the development of skills, ethics and the recognition of social reality, as well as enhancing the health of the population ${ }^{11}$.

Curriculum related issues are considered crucial in professional training, as such documents represent the organized selection of content to be learnt and regulate didactic practice. This is directly related to the structuring of disciplines, the content to be taught by teachers and teaching methods. Thus, curricular guidelines indicate an institutional educational project considered appropriate for professional training at a higher level. They do not always constitute something neutral, universal and immobile, however, but can sometimes be controversial and conflicting ${ }^{12}$.

Humanization is one of the central themes of NCG for dentistry courses, as it is associated with human rights and the possibility of establishing bonds of solidarity ${ }^{13}$. Humanization is people's ability to understand and respect one another. In health care, it is understood as the way of treating patients correctly, with respect, confidence and a broader view of the human being ${ }^{14}$.

In this context, it is necessary that students develop some theoretical elements that help the development of the critical-reflexive capacity and value humanization, representing a position of respect for human life. There is therefore a need to adapt undergraduate courses to enable better training of health professionals and meet the demands of the population ${ }^{13}$. Other issues relate to the generalist training of future dental surgeons, so that they can offer integrated care, know how to work in a team and have a better understanding of reality ${ }^{15}$.

Considering the future of geriatric dentistry, the demand for dental care will become ever greater, and curricula that allow for the improved preparation and development of the subject at undergraduate level will be required ${ }^{16}$.

This aim of the present study was to analyze the teaching of geriatric dentistry from the perspective of the National Curricular Guidelines/Standards for dentistry degree courses in South American countries. 


\section{METHOD}

An exploratory, descriptive study with a qualitative approach was performed, using secondary data collected from a larger scale study. The study universe was the dentistry courses of public universities in five countries in South America: Brazil, Peru, Argentina, Colombia and Chile which included the geriatric dentistry (or similar/equivalent) discipline in their curricula. The inclusion of the universities and of the research participants was performed by intentional sampling.

The participants were 20 professors of geriatric dentistry (or similar/equivalent) from dental education courses in these five countries. The inclusion criteria were the presence of the geriatric dentistry (or similar/equivalent) discipline in the curricula of the dentistry courses of public universities of the five countries, and that the professors had been responsible for the discipline for at least one year. The exclusion criteria were public universities that did not offer the discipline (or similar/equivalent), courses that did not respond or authorize the study after contact by e-mail, substitute professors and those with less than a year teaching the subject.

The baseline study was divided into four stages. In stage 1 , the selection of universities was carried out to obtain information about the discipline (or similar/ equivalent), with 87 dentistry courses analyzed from the five countries. In stage 2 , three criteria were established due to the absence of information on the geriatric dentistry (or similar/ equivalent) discipline. These were: type of discipline (mandatory or otherwise); nature of the discipline (theoretical-practical), and the course load of the discipline. Nine dentistry courses collaborated in the research. In stage 3 the participants were invited to take part, and the coordinators of the dentistry courses were contacted via e-mail, with the approval of the universities. The individuals responsible for the geriatric dentistry (or similar/ equivalent) discipline were then contacted to determine which participants would collaborate with the research, and a total of 20 participating professors were identified. In stage 4 semi-structured open interviews were conducted, using a script in the language of each country. The interviews were conducted online in the second half of 2015 using Skype ${ }^{\circledR}$ software, recorded in digital media and stored using the qualitative data analysis software Atlas.ti (Qualitative Research and Solutions version 7.1.7). A Free and Informed Consent Form (FICF) was issued to each university and participant in the respective language of each country, and all were returned signed by e-mail.

To respond to the proposed objective, the data of the thematic type were analyzed from a curricular perspective, or in other words, based on the formulation of previous categories focusing on the content of the National Curricular Guidelines/ Standards of the five participating countries (Chart 1).

The regulatory guidelines of research involving human being contained in CNS Resolution 466/2012 were followed, and the project was approved under opinion number 984.051 .

\section{RESULTS}

The results are presented through the description and analysis of categories in Chart 2, formulated based on the content of the National Curricular Guidelines/Standards of the five countries studied. 
Chart 1. Summary of National Curricular Guidelines/Standards of South American countries in the study. Florianópolis, 2016.

\begin{tabular}{|c|c|c|c|}
\hline Countries & Document & Scope & Characteristics \\
\hline \multirow{3}{*}{ Brazil } & \multirow{3}{*}{$\begin{array}{l}\text { National Education } \\
\text { Council. Chamber of } \\
\text { Higher Education. } \\
\text { CNE/CES } \\
\text { Resolution dated } \\
\text { February 19, } 2002 . \\
\text { Established national } \\
\text { curricular guidelines } \\
\text { for the undergraduate } \\
\text { course in dentistry. }\end{array}$} & $\begin{array}{l}\text { Profile of } \\
\text { undergraduate/ } \\
\text { professional in } \\
\text { training }\end{array}$ & $\begin{array}{l}\text { - Generalist professional } \\
\text { Strong technical and scientific training } \\
\text { Humanistic } \\
\text { Ethical } \\
\text { Train a dental surgeon with skills } \\
\text { Social awareness } \\
\text { Meet social needs } \\
\text { Do not focus on a technical mindset } \\
\text { Work in both private and public } \\
\text { Commitment to society (citizenship) }\end{array}$ \\
\hline & & Skills & $\begin{array}{l}\text { - Health care: develop prevention, promotion, } \\
\text { protection and rehabilitation actions, both individual } \\
\text { and collective } \\
\text { - Communication: interaction with the public } \\
\text { - Ethical responsibility } \\
\text { - Critical attitude } \\
\text { - Work in multi-professional team }\end{array}$ \\
\hline & & $\begin{array}{l}\text { Teaching-learning } \\
\text { for the education } \\
\text { and training of } \\
\text { the undergraduate } \\
\text { student in dentistry }\end{array}$ & $\begin{array}{l}\text { - Theoretical and practical content, as well as supervised } \\
\text { internship in health and community services } \\
\text { - Knowledge of collective health (knowledge of laws } \\
\text { and public policies) } \\
\text { - Active student participation } \\
\text { - Research } \\
\text { - Continuing Education } \\
\text { - Sound scientific basis }\end{array}$ \\
\hline \multirow{3}{*}{ Peru } & \multirow{3}{*}{$\begin{array}{l}\text { Estándares para la } \\
\text { acreditación de la } \\
\text { carrera profesional } \\
\text { universitaria } \\
\text { de odontología } \\
\text { (CONEAU) }\end{array}$} & $\begin{array}{l}\text { Profile of } \\
\text { undergraduate/ } \\
\text { professional in } \\
\text { training }\end{array}$ & $\begin{array}{l}\text { - Humanist } \\
\text { - Sense of social responsibility } \\
\text { - Suitable academic training } \\
\text { - Aware of the reality of the population } \\
\text { - Ethics }\end{array}$ \\
\hline & & Skills & $\begin{array}{l}\text { - Develop prevention, promotion, protection and } \\
\text { rehabilitation actions in the community } \\
\text { - Have an integral view of the community } \\
\text { - Multidisciplinary work }\end{array}$ \\
\hline & & $\begin{array}{l}\text { Teaching-learning } \\
\text { for the education } \\
\text { and training of } \\
\text { the undergraduate } \\
\text { student in dentistry }\end{array}$ & $\begin{array}{l}\text { - Appropriate to reality } \\
\text { - Knowledge should be provided to enable the care of } \\
\text { patients with special needs } \\
\text { - Theoretical and practical contents as well as supervised } \\
\text { internship in health and community services } \\
\text { - Knowledge of collective health (knowledge of laws } \\
\text { and public policies). } \\
\text { - Active student participation } \\
\text { - Research } \\
\text { - Continuing Education }\end{array}$ \\
\hline
\end{tabular}


Continuation of Chart 1

\begin{tabular}{|c|c|c|c|}
\hline Countries & Document & Scope & Characteristics \\
\hline \multirow{3}{*}{ Chile } & \multirow{3}{*}{$\begin{array}{l}\text { Criterios de } \\
\text { evaluación de } \\
\text { carreras de } \\
\text { odontología } \\
\text { (Comisión Nacional } \\
\text { de Acreditación) }\end{array}$} & $\begin{array}{l}\text { Profile of } \\
\text { undergraduate/ } \\
\text { professional in } \\
\text { training }\end{array}$ & $\begin{array}{l}\text { - Solid knowledge } \\
\text { - Humanist } \\
\text { - Ethical } \\
\text { - Generalist professional }\end{array}$ \\
\hline & & Skills & $\begin{array}{l}\text { - Critical thought } \\
\text { - Continuing learning } \\
\text { - Communication with the community } \\
\text { - Multidisciplinary work }\end{array}$ \\
\hline & & $\begin{array}{l}\text { Teaching-learning } \\
\text { for the education } \\
\text { and training of } \\
\text { the undergraduate } \\
\text { student in dentistry }\end{array}$ & $\begin{array}{l}\text { - Social reality } \\
\text { - Theoretical and practical contents, with out-of- } \\
\text { university visits } \\
\text { - Continuing Education } \\
\text { - Care for all types of patients } \\
\text { - Research }\end{array}$ \\
\hline \multirow{3}{*}{ Colombia } & \multirow{3}{*}{$\begin{array}{l}\text { Hacia un consenso } \\
\text { de las competencias } \\
\text { de formación } \\
\text { del odontólogo } \\
\text { colombiano } \\
\text { (Asociación } \\
\text { Colombiana de } \\
\text { Facultades de } \\
\text { Odontología) }\end{array}$} & $\begin{array}{l}\text { Profile of } \\
\text { undergraduate/ } \\
\text { professional in } \\
\text { training }\end{array}$ & $\begin{array}{l}\text { - Ethics } \\
\text { - Morality } \\
\text { - Humanist } \\
\text { - Social responsibility } \\
\text { - Generalist }\end{array}$ \\
\hline & & Skills & $\begin{array}{l}\text { - Skills for the prevention, promotion, diagnosis and } \\
\text { prognosis of the community } \\
\text { - Acting in multi-professional team } \\
\text { - Critical analysis } \\
\text { - Communication with the community } \\
\text { - Critical attitude } \\
\text { - Knowledge of the population }\end{array}$ \\
\hline & & $\begin{array}{l}\text { Teaching-learning } \\
\text { for the education } \\
\text { and training of } \\
\text { the undergraduate } \\
\text { student in dentistry }\end{array}$ & $\begin{array}{l}\text { - Knowledge of reality } \\
\text { - Work towards quality training } \\
\text { - Research } \\
\text { - Continuing Education } \\
\text { - Knowledge of the country's public policies. } \\
\text { - Humanist }\end{array}$ \\
\hline \multirow{3}{*}{ Argentina } & \multirow{3}{*}{$\begin{array}{l}\text { Apruébanse } \\
\text { los contenidos } \\
\text { curriculares básicos, } \\
\text { la carga horaria } \\
\text { mínima, los criterios } \\
\text { de intensidad de la } \\
\text { formación práctica } \\
\text { y los estándares } \\
\text { para la carrera de } \\
\text { odontología. } \\
\text { Ministerio de } \\
\text { Educación. } \\
\text { Resolución } \\
\text { 1413/2008. }\end{array}$} & $\begin{array}{l}\text { Profile of } \\
\text { undergraduate/ } \\
\text { professional in } \\
\text { training }\end{array}$ & $\begin{array}{l}\text { - Aware } \\
\text { - Generalist dentistry } \\
\text { - Ethic } \\
\text { - Understand the social reality }\end{array}$ \\
\hline & & Skills & $\begin{array}{l}\text { - Apt for development prevention, promotion, } \\
\text { protection and rehabilitation actions, both individual } \\
\text { and collective. } \\
\text { - Multidisciplinary work } \\
\text { - Critical attitude }\end{array}$ \\
\hline & & $\begin{array}{l}\text { Teaching-learning } \\
\text { for the education } \\
\text { and training of } \\
\text { the undergraduate } \\
\text { student in dentistry }\end{array}$ & $\begin{array}{l}\text { - Continuing Education } \\
\text { - Care for all types of patients } \\
\text { - Theoretical and practical contents, also outside the } \\
\text { university } \\
\text { - Active student participation } \\
\text { - Knowledge of the reality of the population } \\
\text { - Research }\end{array}$ \\
\hline
\end{tabular}


Chart 2. Analytical categories and their respective codes. Florianópolis, 2016.

\begin{tabular}{|c|c|}
\hline Category & Code \\
\hline $\begin{array}{l}\text { Profile of Undergraduate/ } \\
\text { Professional in training }\end{array}$ & $\begin{array}{l}\text { - Humanist } \\
\text { - Generalist } \\
\text { - Strong Technical and Scientific training } \\
\text { - Ethical } \\
\text { - Socially responsible: Knowing, being sensitive and committed to social reality } \\
\text { - Acting in the public and private spheres }\end{array}$ \\
\hline Skills & $\begin{array}{l}\text { - Apt to develop actions of prevention, promotion, protection and } \\
\text { rehabilitation, both at individual and collective level } \\
\text { - Multidisciplinary teamwork } \\
\text { - Attitude, critical thinking and continuous learning } \\
\text { - Communication with the community }\end{array}$ \\
\hline $\begin{array}{l}\text { Teaching-learning for the } \\
\text { education and training of the } \\
\text { undergraduate student in dentistry }\end{array}$ & $\begin{array}{l}\text { - Equipped for the reality of the population } \\
\text { - Provide knowledge that enables the care of all patients, including those with } \\
\text { special needs } \\
\text { - Theoretical and practical contents, with visits outside the university } \\
\text { - Continuing Education } \\
\text { - Knowledge of the country's public policies } \\
\text { - Active student participation } \\
\text { - Research and extension }\end{array}$ \\
\hline
\end{tabular}

Profile of the Undergraduate/Professional in Training in dentistry and the teaching of geriatric dentistry

The discourses of the participants indicated one key aspect of professional training: the insertion of the concept of humanization, based on practices that enable the creation of bonds of respect and trust and enabling improvements in people's living conditions and health. The profile required for the training of the future dental surgeon should be created from a new, more extended, concept of health, so that this professional is able to meet the demands of society.

The meaning of a general practitioner for most of the participants is related to the training of someone capable of knowing an individual in their entirety, in the different cycles of life. It is to educate the student to act in a resolutive manner and with responsibility. The participants reinforced the importance of the undergraduate student understanding the process of human aging, in its entirety, and the care required in this age group, with all its peculiarities.

For the participants, it is also important that the teaching-learning process is developed with quality, giving students a solid theoretical and practical training, which allows them to carry their learning into their future professional life. Also, aspects related to ethics are fundamental in the training of students, as they allow them to develop attitudes linked to feelings of citizenship, responsibility and commitment to society.

Professional undergraduate training should not only be aimed at dental care in the private sphere of health systems, but should also prepare students to act in public services, meeting the needs of the user population, especially the elderly. Thus, it is necessary to value and know how to apply preventive measures to the diseases that most affect this population group, as well as health promotion strategies, and not restrict performance to curative care through specific clinical procedures.

According to the statements of some participants, one of the relevant topics highlighted in the category of Skills to be developed by undergraduate students in dentistry are related to the formation of future health professionals in the expanded sense, including competences to be developed in actions of health promotion, the prevention and protection of diseases and illnesses, treatment and rehabilitation, allowing them to develop comprehensive care of the population at all levels. A university should 
prepare its students to carry out these actions with the elderly, allowing them to have a better quality of life, since in this group there is a high prevalence of chronic conditions that cause their health status to deteriorate, with repercussions for oral health.

For the interviewees, the university is one of the institutions responsible for helping students to discover the necessary tools for a better understanding of teamwork, through participation and coexistence with professionals from other areas.

Students must be prepared to treat all kinds of people during their degree courses and teachers and professors can help them become more critical and able to solve problems and make decisions in a responsible way. Learning does not end with graduation and should continue throughout life, so students should be able to think clearly about their own learning process, noting successes and errors, leading to a successful professional life, according to the participants.

According to the interviewees, it is also important for students to learn to relate to and communicate with people, especially with elderly persons, so as to be more resolutive and confident when dealing with this population group.

In the discourses of some of the interviewees, it can be observed that one of the key topics in the teaching-learning of geriatric dentistry for undergraduate students training in dentistry is the knowledge that the undergraduate student should have about the social reality of his country. It is important that university curricula are flexible and adjusted to the local reality to train professionals who are more committed to the health of the population. The student should be aware that the population is aging and adopt an overview of the reality of living conditions and health of this population group. They should be prepared to perform care for people of all ages. Thus, the association between theory and practice, in the case of geriatric dentistry, helps the student to better understand the world of this population and know their specificities, resulting in a better professional performance in the care of the elderly.

The interviewees also point out that the participation of the teacher is fundamental in the student's teaching-learning process, as it provides students with the confidence to express and let their ideas flow, to help them feel confident, and to provide them, through a range of strategies, with the necessary tools that allow students to participate more actively in the classroom, so developing different important skills in the management of elderly patients.

The interviewees reported that with the passing of time people face changing difficulties, which can alter their health status, requiring a more individualized service. This is the situation in most countries in South America. Often, the elderly population is fragile, and not valued or respected, even when public policies protect them. Thus, it is important to train future professionals who enjoy working with the elderly and have the ability to articulate and defend the rights of this group.

\section{DISCUSSION}

The NCG serve as a guide in the curricular development of dentistry courses, enabling strategies for a successful teaching-learning process for future professionals ${ }^{17}$. The changes in the curricula of dentistry courses have transposed the traditional curriculum to form future generalist-based dentists with critical and reflexive capacities, in order to attend to the health needs of the population, enabling them to develop their activities in a responsible and creative way $^{18}$. Thus, it is important to point out that curricula go beyond the content traditionally acquired in school subjects, circumscribing their educational objectives, with constant revision and modification. They therefore play important roles in broadening the world view of students and promoting citizenship, tolerance and solidarity ${ }^{12}$.

NCG, in general, indicate the need to train humanized professionals, an essential aspect of caring for human beings. Unfortunately, this aspect has not been considered in student training ${ }^{19}$. By promoting humanization in dentistry courses, the guidelines contribute to the training of professionals who are more aware of reality ${ }^{19}$.

It is important that students are able to perform dental care for people of different ages. The elderly in particular require diverse types of care, and so it is necessary to create environments in which the student broadens their knowledge and develops 
care skills related to this population group ${ }^{20}$. With the objective of training future dental surgeons capable of caring for the elderly, it is necessary that the discipline of geriatric dentistry is present in dental curricula, addressing aspects of the oral health of the elderly and their particularities and allowing students to develop skills related to the care of this age group ${ }^{11}$.

With regard to the development of the discipline of geriatric dentistry, it is necessary for universities to provide students with a number of situations that allow them to increase their awareness of these issues, leading to better management of the elderly, in order to offer a quality care, fulfilling one of the purposes proposed by the NCG for the suitable training and education of future professionals ${ }^{10}$. This topic was little explored by the participants of the study, which suggests some difficulty in the execution of the disciplines.

Other results highlighted in this study relate to the integrated training of the students, emphasizing technical, scientific, ethical and socially responsible training. With technological and scientific advances it is indispensable that higher education institutions focus more on student learning, with suitable educational environments and techniques. Dentistry courses should train future professionals to be aware of the social, economic and general health and oral reality of the population, and not just train technically competent and highly specialized students ${ }^{21}$. Ethics is also a major challenge in the training of future health professionals as it enables them to develop competently and be responsible professionals ${ }^{22}$.

According to the National Curricular Guidelines ${ }^{23}$, when training dentistry students need to be able to carry out health promotion, prevention and rehabilitation actions, either individually or collectively, in order to analyze and offer solutions to the problems of the population. Dentistry courses have difficulties in terms of their curricula, with shortcomings identified in relation to the preventive and promotional aspects of oral health ${ }^{24}$.

The training of future dental surgeons should include preparing them to work in a multi-professional manner and to recognize the work of other health professionals ${ }^{25}$. The changes in dentistry curricula seek to strengthen critical thinking as one of the fundamental skills in student training, allowing these individuals to better understand life and place themselves within reality to solve problems more effectively and make decisions in a responsible way ${ }^{26}$. Dentistry training must be combined with critical thinking, preparing the student for an integrated and more human formation ${ }^{27}$.

Communication is among the skills that every good dental surgeon should possess. The teachinglearning process, based on the diversification of practical scenarios, will enable students to deal with the reality of this population and also to develop their communication skills ${ }^{28}$.

Also highlighted in this study was the knowledge that dentistry students should have about the reality of their country. Curricula must be adapted to the reality of society, which poses new demands and challenges. The future dental surgeon must be prepared to understand the reality that surrounds the elderly population, the aging process and the living and health conditions of this age group ${ }^{29}$.

The application of strategies related to theoreticalpractical content for a more solid formation of the student was also discussed. With regard to the care of the elderly, in order for a student to better understand the world of this population group, and to know that they need a different type of service, it is necessary to combine the knowledge imparted in theory with practical activities, allowing them to develop the necessary skills for more effective management and oral health care of this age group ${ }^{30}$.

Public policies for the elderly were created to guarantee their rights and allow them to live in safety and comfort. With the increase in the elderly population, it is important to implement wellstructured policies for better population aging. In undergraduate courses, it is essential that dentistry students learn about public policies and how they affect society's problems ${ }^{31}$.

One of the ways in which students can have greater contact with the elderly is through the implementation of university extension programs, allowing them to approach this population in a different manner ${ }^{20}$. 
This study has some limitations, as it is a rereading of data collected in another study with a broader scope. There were also no face-to-face interviews, which prevents real interaction with the participants. Finally, the documents relating to the National Curricular Guidelines/Standards were surveyed on electronic sites, meaning that there was no guarantee they had been updated, which may interfere in their interpretation.

\section{CONCLUSION}

The present study showed that the National Curricular Guidelines/Standards for dentistry courses in the five countries studied have similarities in terms of the norms that guide the training/education of future dental surgeons, as well as with regard to the competencies that dentistry aims to develop and the form of the teaching-learning process during their degree courses.

The data indicate that the teaching of dentistry seeks to establish a connection with the recommendations of the National Curricular
Guidelines/Standards for the training of dental surgeons, since these refer, in a general way, to the form the preparation and development of the future professional should take. However, the simple insertion of the geriatric dentistry discipline into the curricula of the undergraduate courses is not enough to ensure a process of teaching and learning that allows the student to develop skills to provide better care for the elderly. These skills should be in line with the more general Curricular Guidelines/ Standards, and thus, reflect on the formation of the student/ professional as a generalist professional.

The present study opens space for reflection on the importance of forming socially responsible dentists, the indispensable accomplishment of the National Curricular Guidelines/Standards for guiding dentistry courses towards better training/ education of students and also the necessity that the teaching of geriatric dentistry is aligned and reflects the guidelines of the aforementioned National Curricular Guidelines/Standards to train future professionals who can impact the life and health of the elderly population in South America.

\section{REFERENCES}

1. Chile. Instituto nacional de estadística. Demográficas y Vitales [Internet]. Chile: INE; 2016 [acesso em 13 jan. 2016]. Disponível em: www.ine.cl/canales/chile_ estadistico/familias/demograficas_vitales.php

2. Instituto Brasileiro de Geografia e Estatística. Projeção da População do Brasil por sexo e idade: 2000-2060 [Internet]. Rio de Janeiro: IBGE; 2016 [acesso em 13 jan. 2016]. Disponível em: http://www. ibge.gov.br/home/estatistica/populacao/projecao_ da_populacao/2013/default_tab.shtm

3. Colômbia. Departamento Administrativo Nacional de Estadística. Proyección de Población [Internet]. Colombia: DANE; 2016 [acesso em 13 jan. 2016]. Disponível em: http://www.dane.gov.co/index. php/estadisticas-por-tema/demografia-y-poblacion/ proyecciones-de-poblacion.

4. Argentina. Instituto Nacional de Estadística y Censo. Proyecciones y Estimaciones [Internet]. Argentina: INDEC; 2016 [acesso em 13 jan. 2016]. Disponível em: http://www.indec.gob.ar/nivel4_default.asp?id_ tema_1=2\&id_tema_2=24\&id_tema_3=84
5. Peru. Instituto Nacional de Estadística e Informática. Población y Vivienda [Internet]. Peru: INEI; 2016 [acesso em 13 jan. 2016]. Disponível em: www.inei.gob. pe/estadisticas/indice-tematico/poblacion-y-vivienda/

6. Miranda GMD, Mendes ACG, Silva ALA. O envelhecimento populacional brasileiro: desafios e consequências sociais atuais e futuras. Rev Bras Geriatr Gerontol. 2016;19(3):507-19.

7. Ettinger RL. A 30-year review of a geriatric dentistry teaching programme. Gerodontology. 2012;29(2):1252-60.

8. Macedo IAB, Oliveira CCC, Freitas MMD, Nunes MAR. Odontogeriatria e necessidade curricular-relato de acadêmicos da UNIT-SE. Odontol Clín.-Cient. 2002;1(2):109-122.

9. Martins Neto M. Odontogeriatria: avaliação clínica da saúde bucal e do uso do fumo em grupos de idosos. Santa Cruz do Sul: EDUNISC; 2013.

10. Ogawa D, HigasI MS, Caldarelli PG. Odontogeriatria nos projetos políticos pedagógicos dos cursos de odontologia do sul do Brasil. Rev ABENO. 2015;15(4):78-84. 
11. Salvagnin MCA. O ensino da Odontogeriatria no currículo do curso de graduação em odontologia no Estado de São Paulo [Dissertação]. São Paulo: Universidade Federal de São Paulo; 2006.

12. Sacristán JG. Saberes e incertezas sobre o currículo. Porto Alegre: Penso; 2013.

13. Casate JC, Corrêa AK. A humanização do cuidado na formação dos profissionais de saúde nos cursos de graduação. Rev Esc Enferm USP. 2012;46(1):219-26.

14. Lima ENA, Souza ECF. Percepção sobre ética e humanização na formação Odontológica. Rev Gaúch Odontol. 2010;58(2):231-38.

15. Morita MC, Kriger L, Carvalho ACP, Haddad AE. Implantação das Diretrizes Curriculares Nacionais em odontologia. Maringá: Dental Press; 2007.

16. Gleiser- Boiko E, Malamud C, Kessler. Visión presente y futuro de la odontogeriatría en el Perú. Actual Odontol Salud. 2015;12(1):5-7.

17. Araújo RPC, Mello SMF. Curso de graduação em odontologia: a formação docente. Pesqui Bras Odontopediatr Clín Integr. 2011;11(4):615-25.

18. Takemoto M, Werlang F, Zeni E. O legado das Diretrizes Curriculares Nacionais no ensino odontologico. Rev. Tecnol. 2015;2(1):393-401.

19. Canalli CSE, Silveira RG, Miasato JR, Chevitarese L. Humanização na relação cirurgiõe-dentista-paciente. Rev Odontol Univ Cid São Paulo 2012;24(3):220-5.

20. Moimaz SAS, Garbin CAS, Lolli LF, Dossi AP, Nayme JGR. Percepção de acadêmicos de odontologia sobre o envelhecimento. Rev Odontol UNESP. 2010;39(4):227-31.

21. Fonseca EP. As Diretrizes Curriculares Nacionais e a formação do cirurgiõe-dentista brasileiro. J Manag Prim Health Care. 2012;3(2):158-78.

22. Finkler M, Caetano JC, Ramos FRS. Ética e valores na formação profissional em saúde: um estudo de caso. Ciênc Saúde Coletiva. 2013;18(10):3033-42.
23. Conselho Nacional de Educação, Câmara de Edução Superior. Resolução CNE/CES no 3, de 19 de fevereiro de 2002. Institui Diretrizes Curriculares Nacionais do Curso de Graduação em Odontologia. Portal Mec. 2015. Disponível em: http://portal.mec. gov.br/cne/arquivos/pdf/CES032002.pdf

24. Toassi RFC, Souza JM, Berggrav E, Purper LB, Rosing CK. Avaliação curricular na educação superior em odontologia reflexões a partir da perspectiva dos estudantes. In: Anais do $11^{\circ}$ Colóquio Internacional sobre gestão Universitária na América do Sul; $2^{\circ}$ Congresso Internacional IGLU; 7-9 de dezembro de 2011; Florianópolis. Florianópolis: UFSC; 2012. p. 1-10.

25. Carcereri DL, Amante CJ, Reibnitz MT, Mattevi GS, Silva GG, Padilha ACL, et al. Formação em odontologia e interdisciplinaridade: o pró-saúde da UFSC. Rev ABENO. 2011;11(1):62-70.

26. Farias CML, Carvalho RB, Laiber LP, Belotti L, Pacheco KTS. Pensamento crítico e a formação de profissionais em odontologia: uma revisão narrativa da literatura. Rev ABENO. 2016;16(1):73-87.

27. Gabriel M, Tanaka EE. Formação profissional em odontologia: percepão discente da interação curricular. Rev ABENO. 2011;11(1):19-22.

28. Tôrres LHN. Cenário diversificado na formação do aluno de graduação em odontologia. Odontol Clín.Cient. 2013;12(3):203-7.

29. Núñez MRR, Godoi H, Mello ALSF. Panorama do ensino da Odontogeriatria nas universidades públicas brasileiras. Rev Fam Ciclos Vida Saúde Contexto soc. 2016;4(3):237-45.

30. Shah N. Teaching, learning, and assessment in geriatric dentistry: researching models of practice. J Dent Educ. 2010;74(1):20-8.

31. Bulgarelli AF, Souza KR, Baumgartem A, Souza JM, Rosing CK, Toassi RFC. Formação em saúde com vivência no Sistema Único de Súde (SUS): percepção de estudantes do curso de odontologia da Universidade Federal do Rio Grande do Sul (UFRGS), Brasil. Interface. 2014;18(49):351-62. 